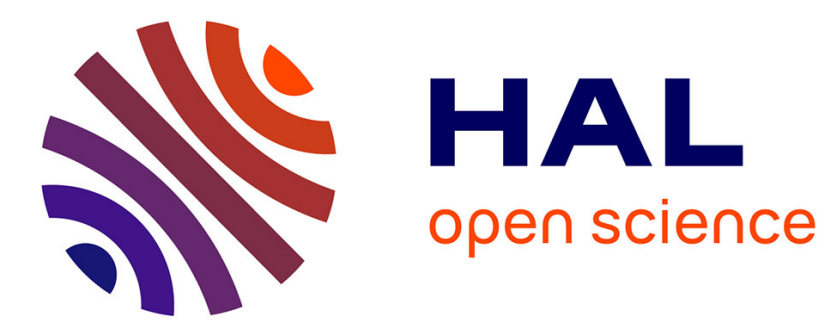

\title{
Semen cultures analysis: retrospective study during a 6-year period and interest in the management of infertility
}

M. Leterrier, T. Fréour, A. Guillouzouic, M.-E. Juvin, P. Barriere, A. Reynaud, S. Corvec

\section{To cite this version:}

M. Leterrier, T. Fréour, A. Guillouzouic, M.-E. Juvin, P. Barriere, et al.. Semen cultures analysis: retrospective study during a 6-year period and interest in the management of infertility. European Journal of Clinical Microbiology and Infectious Diseases, 2010, 30 (3), pp.401-406. 10.1007/s10096010-1100-2 . hal-00639783

\section{HAL Id: hal-00639783 https://hal.science/hal-00639783}

Submitted on 10 Nov 2011

HAL is a multi-disciplinary open access archive for the deposit and dissemination of scientific research documents, whether they are published or not. The documents may come from teaching and research institutions in France or abroad, or from public or private research centers.
L'archive ouverte pluridisciplinaire HAL, est destinée au dépôt et à la diffusion de documents scientifiques de niveau recherche, publiés ou non, émanant des établissements d'enseignement et de recherche français ou étrangers, des laboratoires publics ou privés. 


\section{Original Article V2 EJCMID-D-10-00353}

Semen cultures analysis : retrospective study during a six-year period and interest in the management of infertility

6

8

10 Concise title : Management infertility and semen culture analysis

Leterrier M. ${ }^{1}$, Fréour T. ${ }^{3}$, Guillouzouic A. ${ }^{1,2}$, Juvin M-E. ${ }^{1}$, Barriere P. ${ }^{3}$, Reynaud A. ${ }^{1,2}$, Corvec S. ${ }^{1,2}$ 16

${ }^{1}$ CHU de Nantes, Service de Bactériologie-Hygiène, 9 quai Moncousu 44093 Nantes, F-44000

18 France

${ }^{2}$ Université de Nantes, Faculté de Médecine, EA3826 Thérapeutiques cliniques et expérimentales des infections, 1 rue G. Veil 44035 Nantes, F-44000 France

${ }^{3}$ CHU de Nantes, Service de Médecine et Biologie du Développement et de la Reproduction, 38 Bd 24 Jean Monnet 44093 Nantes, F-44000 France

${ }^{*}$ Corresponding author. S. Corvec CHU de Nantes, Service de Bactériologie-Hygiène Tel. : +332400839 55; Fax : +332400839 28; 


\section{Abstract}

Purpose : In the past decade, the number of couples consulting an Assisted Reproductive

42 Techniques (ART) center for infertility has increased in most European countries. In France, sperm bacterial examination must be performed every 6 months in couples undergoing In Vitro

44 Fertilization (IVF) cycles, according to 2010 French ART Guidelines. The aim of this study was to analyze the results from such samples at Nantes University Hospital and to assess their potential

46 value for infertile couples undergoing ART cycles.

Methods : Between 2003-2008, semen cultures performed were analyzed according to bacterial enumeration, type and number of bacterial species and their antibiotic resistance profile.

Results and discussion : 14,119 semen cultures were performed showing an annual increase of 45

$50 \%$ from the start to the end of the study. The proportion of positive semen cultures was stable throughout the study period (40 to $45 \%$ ). Many bacterial species were considered as contaminants

52 (coagulase-negative staphylococci, alpha-hemolytic streptococci). For pathogen agents (in most cases Enterobacteriaceae), the antibiotic resistance profile revealed mostly a susceptible phenotype.

54 At last, every positive bacterial result had direct consequences on IVF cycle management, with subsequent reinforced advice on hygiene procedure before sample collection and/or antibiotics 56 prescription.

$58 \quad 197$ words

60 
66 In France, over the past decade, an increasing number of couples consulted an Assisted Reproductive Techniques (ART) center for the management of infertility [1]. In this framework, a clinical and biological assessment of infertility is realized for each partner. For men, this assessment systematically requires a semen analysis including a microbiological semen culture [2-3]. This bacteriological analysis is indicated for the safety of the partner and to optimize the preparation of the semen before insemination [4]. The purpose of the semen culture is to identify a possible bacteriospermia in order to eradicate it and to prevent contamination of embryonic culture media. A positive bacterial culture could result in fertilization failure and altered embryonic development,

74 leading to lowered pregnancy rates, making it an essential consideration before in vitro fertilization (IVF) cycle.

76 This analysis has to be performed in a systematic fashion, as most men are asymptomatic. Indeed, chronic bacterial infection of semen is rare, but may be a potential cause of male infertility [5]. Bacteria involved in that case could act on semen quality either directly on spermatozoa (spermatozoa motility and viability), or indirectly on the seminal plasma or by forming anti-semen antibodies [5]. Semen bacterial analysis can recover various bacterial species, including potential pathogens (i.e. Enterobacteriaceae or Staphylococcus aureus), but also bacterial species usually considered as contaminants (coagulase-negative staphylococci, alpha-hemolytic streptococci...) originating from the urethral or cutaneous flora $[5,6]$.

The aim of this study was to evaluate the results of semen analysis in the bacteriology laboratory at Nantes University hospital and to assess the relevance of the procedure in the global management of infertile patients. 


\section{Materials and methods}

92 This retrospective study has been conducted at Nantes University Hospital for a six-year period, between 2003 and 2008 .

94

\section{Patient selection}

During the study period, each bacterial semen analysis performed was included. Most of the men were referred for semen analysis before an IVF cycle (approximately 2000 per year ; semen analysis was performed after a first infertility consultation or 6 weeks before each IVF cycle ; control semen analysis was performed after antibiotherapy). Others were semen donor or men referred for semen cryopreservation before potentially gonadotoxic treatment.

\section{Bacteriological analysis of semen}

\section{Sample collection procedure}

104 Before semen analysis, men were previously instructed to drink abundantly (generally, up to 1.5 liter) the day before semen collection in order to increase diuresis and to assure a cleaning of the urethra, as previously reported [6]. Semen samples were collected at the ART center after 2 to 3 days of sexual abstinence. Just before semen collection, both verbal and written advices were given

108 by the medical team to the patient to follow a drastic hygiene procedure : first, men were asked to wash hands, then to urinate and finally to wash their penis with chlorhexidine (aqueous 110 chlorhexidine, $0.05 \%$, one dose recipient, Gilbert laboratory, France). Semen was collected in an aseptic recipient (MT245, JCD, La Mulatiere, France) after masturbation and analyzed after 30

112 minutes of liquefaction at $37^{\circ} \mathrm{C}$. 
After collection of the ejaculate into a sterile plastic receptacle, samples were aliquoted. Semen

118 aliquots $(150 \mu \mathrm{L})$ were transferred within three hours to the bacteriology laboratory to quantify aerobic rods only [7]. Semen samples were plated pure $(10 \mu \mathrm{L})$ and diluted with sterile saline solution at 1:10 $(100 \mu \mathrm{L})$ on horse blood agar plates (bioMérieux, Marcy-l'Etoile, France). Media were incubated for 24 to 48 hours in atmosphere supplemented with $5 \%$ of $\mathrm{CO}_{2}$ at $37{ }^{\circ} \mathrm{C}$.

\section{Diagnostic procedure}

124 Each colony from the plate inoculated with diluted semen represented $10^{2} \mathrm{CFU} \mathrm{mL}{ }^{-1}$. The bacterial enumeration was categorized as follows : enumeration less than $10^{3} \mathrm{CFU} \mathrm{mL}^{-1}$ was considered as negative cultures according to WHO criteria [2] ; enumeration from $10^{3} \mathrm{CFU} \mathrm{mL} \mathrm{m}^{-1}$ to $3 \times 10^{3} \mathrm{CFU}$ $\mathrm{mL}^{-1}$ or enumeration up to $3 \times 10^{3} \mathrm{CFU} \mathrm{mL} \mathrm{mL}^{-1}$ were considered as positive cultures, in the case of

128 pure or predominant flora culture. According to the World Health Organization guidelines [2], a bacterial concentration in the ejaculate up to $10^{3}$ bacteria $\mathrm{mL}^{-1}$ is a significant bacteriospermia.

130 Therefore, no qualitative analysis was realized for samples with enumeration less than to $10^{3} \mathrm{CFU}$ $\mathrm{mL}^{-1}$.

132 If necessary, bacteria were identified by fast and simple tests such as Lancefield's group determination for streptococci (Streptex ${ }^{\circledR}$, DiaMondial, Sees, France) and agglutination test for

134 staphylococci (Statest ${ }^{\circledR}$, Biorad, Marnes-la-Coquette, France). For Enterobacteriaceae biochemical identification was performed using the Vitek $2^{\circledR}$ IDGN card (bioMérieux) and Api Coryne ${ }^{\circledR}$ 136 (bioMérieux) for Corynebacterium seminale.

Susceptibility testing was systematically performed on bacterial strains potentially pathogenic or resistant to antibiotics such as Enterobacteriaceae (VITEK2 ${ }^{\circledR}$ AST-N052, bioMérieux), Staphylococcus aureus (VITEK2 ${ }^{\circledR}$ AST-P551, bioMérieux) and C. seminale (disc diffusion 140 technique on horse blood agar plates at $37^{\circ} \mathrm{C}$ in an atmosphere supplemented with $5 \%$ of $\mathrm{CO}_{2}$ ). An antibiotic treatment was indicated in the following cases : 
142 When an Enterobacteriaceae or a S. aureus was detected, an antibiotic treatment with good urogenital diffusion was recommended. Antibiotic regimen was in first intention, nitrofurantoine (150

144 mg per day, 8 days except for Proteus-Providencia-Morganella) or in second intention, ofloxacine (400 mg per day, 10 days). Antibiotherapy was adapted according to susceptibility testing and a

146 control semen culture was systematically performed 10 days after the end of the treatment in order to check the efficiency of the antibiotherapy.

148 When $C$. seminale was detected associated with leucospermia, an antibiotic treatment with good uro-genital diffusion was also recommended.

150 On the opposite, no antibiotic treatment was established for the patient (i) when a monomicrobial culture of Enterococcus (enumeration up to $3 \times 10^{3} \mathrm{CFU} \mathrm{mL} \mathrm{m}^{-1}$ ) was detected, but a control semen

152 culture was systematically performed or (ii) when a plurimicrobial culture (i.e. up to $3 \times 10^{3} \mathrm{CFU}$ $\mathrm{mL}^{-1}$ ) with cutaneous flora bacteria or Enterococcus was observed, suggesting a contamination 154 during semen collection.

\section{Results}

158 Quantitative analysis

From January $20031^{\text {st }}$ to December $200831^{\text {th }}$, 14,119 samples from 7,723 men were included in 160 this study, representing an average of 1,287 patients per year.

The activity increased from 1,843 samples in 2003 to 2,664 in 2008, (+ $45 \%$ - Figure 1). Although

162 the ratio of requests per patient was stable (ranging from 1.74 to 1.86 between 2003 and 2008), there was a $35 \%$ increase in the number of patients consulting and then included in the ART 164 program (1,060 in 2003 to 1,435 patients in 2008), reflecting the increasing activity of the ART center during the study period.

166 The results have been interpreted according to bacterial enumeration and number of species recovered (Table 1). Very few samples were classified as non-interpretable due to the invasion of 
168 the culture by Proteus species. Furthermore, for a limited number of samples, the volume was insufficient for bacterial enumeration. The percentage of positive semen cultures was relatively 170 stable during the 6 years with an average of $44.8 \%$ (39.9 to $46.6 \%)$, respectively $11 \%$ with a bacterial enumeration from $10^{3} \mathrm{CFU} \mathrm{mL}^{-1}$ to $3 \times 10^{3} \mathrm{CFU} \mathrm{mL}^{-1}$ and $33.8 \%$ with an enumeration up to $3 \times 10^{3} \mathrm{CFU} \mathrm{mL} \mathrm{m}^{-1}$. Whatever the enumeration for positive semen cultures, a majority of these samples was polymicrobial $(77 \%)$.

\section{Qualitative analysis : bacterial ecology of semen samples}

176 The different types of bacteria recovered from semen cultures are summarized in Table 2. In most cases, they corresponded to bacteria considered as contaminants or "belonging" in the male genital

178 tract (average : $50.3 \%$ ). These results were confirmed all over the study period. Enterococci were found from 10.5 to $24.4 \%$ of the isolated species and Enterobacteriaceae from 11.7 to $27.5 \%$, mostly Escherichia coli $(57.1 \%$ to $65.6 \%)$.

\section{Resistance pattern of the bacteria recovered}

Between 2003 and 2008, out of the 14,119 semen cultures performed, 1,376 antibiotic susceptibility tests were realized $(9.75 \%)$. In 2003, according to our criteria, $16.7 \%$ of the requests required an antibiotic susceptibility test compared with $7.2 \%$ in 2008 (Table 3). In most cases, regardless of the identified species, a susceptible phenotype was generally recovered. Isolation of multi-drugresistant bacteria (MDR) remained an exceptional phenomenon as shown in table 3. Six of these 10 cases concerned Enterobacteriaceae resistant to third-generation cephalosporins. Most of the corresponding patients had spinal cord injury resulting in paraplegia, with a permanent urinary 190 catheter. 
196 This retrospective study during a six-year period revealed a $45 \%$ increase in the annual number of semen cultures requests. Over a 10 year period (1998-2008) this increase was $137 \%$ with a $72 \%$ increase of the number of patients consulting the ART center and a doubling of the number of medical consultations from 2003 to 2008 (data not shown). These observations are part of the 200 national trend of increasing number of couples consulting for infertility [1].

It could be partly due to the increasing maternal age at the time of the first pregnancy in most

202 European countries (30 years in France) [8]. Moreover, improved and extensive medical and media information about infertility allows faster and more efficient referral of couples experiencing 204 difficulties to conceive to ART centers.

206 During this study, the proportion of positive semen cultures remained stable during the study period with an average of $44.8 \%$. Previously reported data appeared to be highly variable from one study to another. Indeed, values ranging from 20 to a surprising $100 \%$ of positive semen cultures were reported [5-6, 9-12]. For example, Virecoulon et al worked with a threshold of $10^{3} \mathrm{CFU} \mathrm{mL}^{-1}$ [6].

210 Stovall et al reported $69 \%$ of positive cultures with a threshold of $10^{2} \mathrm{CFU} \mathrm{mL}^{-1}$ [13]. Moretti et al worked with a threshold of $10^{4} \mathrm{CFU} \mathrm{mL} \mathrm{m}^{-1}$ in case of Gram positive cocci but a $10^{5} \mathrm{CFU} \mathrm{mL}^{-1}$ in case

212 of Gram negative rods [12]. Finally, comparison between different studies is difficult since some authors do not mention a specific positivity threshold [5].

214 An interesting parameter to consider is the influence of hand washing on the number of positive semen cultures. Indeed, a study among couples followed for IVF has shown that the number of 216 positive semen cultures could fall from 92.9 to $39 \%$ with instructions for washing hands before sampling [14]. Furthermore, Boucher et al. have shown that direct verbal counseling of patients by 218 a member of the medical staff improved the bacterial quality of the sample compared with short written instructions [15]. In our study, there was no change in the procedure of the ART center for 
semen sampling (verbal instructions) and the bacterial ecology of semen sample was relatively stable during the 6 years.

According to the results, a large proportion of species can be considered as contaminants, resulting from bad asepsis during sampling in agreement with the literature [5-6,12]. High-prevalences for coagulase-negative staphylococci (CNS) and for alpha-haemolytic streptococci were previously reported $[5,13]$. CNS usually predominate in the distal urethra and reflect the aerobic and facultative bacterial ecosystem of the male genital tract.

228 In our cohort, there was also a large proportion of enterococci which is controversial in the literature. For example, Rodin et al. found a low proportion of $7.4 \%$ [16]. Different teams have 230 worked on the role of enterococci in infertility and as far as we know, only one study suggested an high incidence of oligozoospermia and teratozoospermia in human semen infected with E. faecalis

232 [17]. Although the French guidelines in Microbiology recommended systematic search for anaerobes [18], due to contradictory data in the literature, these bacteria were not searched. Indeed, anaerobes normally colonize the male urethral orifice and therefore are not considered to be a major cause of male infertility [7]. Urogenital Mycoplasma spp. were not systematically searched in agreement with the clinicians and biologists of the ART center except for specific request [19].

238 For Enterobacteriaceae, different data from the literature found a proportion of around 15 to $20 \%$ [5,20], which is in agreement with our results. A recent study has shown their potential role in 240 semen motility alteration [21]. Presence of Enterobacteriaceae in semen involves the prescription of antibiotic treatment, with a significant potential impact on the digestive flora [22]. Here, the 242 presence of Enterobacteriaceae in semen involved a delay in the IVF procedure but had no influence on the assisted reproductive technique outcome. The management of patients was shifted :

244 the IVF procedure was not started before negative semen culture was obtained, confirming that the semen was free of infection. 
246 The impact of bacteriospermia on semen parameters remains controversial [5, 13, 14, 20, 23]. Berktas et al. have shown the negative impact of certain species such as Enterobacteriaceae on semen motility in vitro [21]. Merino et al. found that bacterial infection can cause alteration in seminal characteristics, such as volume, motility and viability [5]. Nevertheless, the lack of association between bacteriospermia and abnormal semen parameters or the occurrence of adverse events in IVF was also reported [13-14, 23]. However, bacterial examination of semen remains necessary before IVF to avoid contamination of culture media, especially for those who do not contain antibiotics, which is the case in our IVF center.

254 Regarding antibiotic resistance, whatever the species studied, antibiotic susceptibility testing revealed mostly a susceptible phenotype. Only ten multi-drug-resistant (MDR) bacteria isolated were recovered during the six-year period. Clinical data analysis revealed that most patients with MDR bacteria had spinal chord injury and consequent paraplegia, leading to permanent urinary catheter use with potential repeated antibiotic regimens.

\section{References}

1. Agence de biomédecine. (2009) Bilan des activités de procréation et de génétique humaines en France en 2006. (http://www.agencebiomedecine.fr/annexes/bilan2008/som/som_general_proc.htm)

2. World health Organization. (2010) Laboratory manual for the examination of human semen and semen-cervical mucus interaction. $5^{\text {th }}$ edn. Cambridge University Press.

3. Kvist U, Bjorndahl L. (2002) Manual on basic semen analysis. ESHRE Monographs (2). Oxford, 266 UK: Oxford University Press.

268 4. Askienazy-Elbhar M. (2005) Male genital tract infection : the point of view of the bacteriologist. Gynecol Obstet Fertil 33:691-697.

5. Merino G, Carranza-Lira S, Murrieta S, Rodriguez L, Cuevas E, Morán C. (1995) Bacterial infection and semen characteristics in infertile men. Arch Androl 35:43-47.

6. Virecoulon F, Wallet F, Fruchart-Flamenbaum A, Rigot JM, Peers MC, Mitchell V, Courcol RJ. 274 (2005) Bacterial flora of the low male genital tract in patients consulting for infertility. Andrologia 37:160-165.

276 7. Keck C, Gerber-Schäfer C, Clad A, Wilhelm C, Breckwoldt M. (1998) Seminal tract infections: impact on male fertility and treatment options. Hum Reprod Update 4:891-903. 
278 8. Auger J, Kunstmann JM, Czyglik F, Jouannet P. (1995) Decline in semen quality among fertile men in Paris during the past 20 years. N Engl J Med 2:281-285.

280 9. Swenson CE, Toth A, Toth C, Wolfgruber L, O'Leary WM. (1980) Asymptomatic bacteriosemenia in infertile men. Andrologia 12:7-11.

282 10. Levy R, Grattard F, Maubon I, Ros A, Pozzetto B. (2004) Bacterial risk and semen cryopreservation. Andrologia 36:282-285.

284 11. Cottell E, Lennon B, McMorrow J, Barry-Kinsella C, Harrison RF. (1997) Processing of semen in an antibiotic-rich culture medium to minimize microbial presence during in vitro fertilization.

286 Fertil Steril 67:98-103.

12. Moretti E, Capitani S, Figura N, Pammolli A, Federico MG, Giannerini V, Collodel G. (2009)

13. Stovall DW, Bailey LE, Talbert LM. (1993) The role of aerobic and anaerobic semen cultures in asymptomatic couples undergoing in vitro fertilization: effects on fertilization and pregnancy rates. Fertil Steril 59:197-201.

14. Krissi H, Orvieto R, Ashkenazi J, Gilboa Y, Shalev J, Moscovitch I, Bar-Hava I. (2004) Effect of contaminated preprocessed semen on fertilization rate and embryo quality in assisted reproductive techniques. Gynecol Endocrinol 18:63-67.

15. Boucher P, Lejeune H, Pinatel MC, Gille Y. (1995) Semenoculture : improvement of the bacteriological quality of samples by direct verbal counseling before semen collection. Fertil Steril 64:657-660.

16. Rodin DM, Larone D, Goldstein M. (2003) Relationship between semen cultures, leukosemenia, and semen analysis in men undergoing fertility evaluation. Fertil Steril 79s:15551558.

17. Mehta RH, Sridhar H, Vijay Kumar BR, Anand Kumar TC. (2002) High incidence of oligozoosemenia and teratozoosemenia in human semen infected with the aerobic bacterium Steptococcus faecalis. Reprod Biomed Online 5:17-21.

308 18. SFM. (2007) Examen des sécrétions et exsudats anogénitaux. In REMIC : Vivactis Plus Ed ; pp. 43-48.

310 19. Rosemond A, Lanotte P, Watt S, Sauget AS, Guerif F, Royère D, Goudeau A, Mereghetti L. (2006) Systematic screening tests for Chlamydia trachomatis, Mycoplasma hominis and 312 Ureaplasma urealyticum in urogenital specimens of infertile couples. Pathol Biol 54:125-129.

314 20. Sanocka-Maciejewska D, Ciupinska M, Kurpisz M. (2005) Bacterial infection and semen quality. J Reprod Immunol 7:51-56. 
22. Andremont A. (2000) Consequences of antibiotic therapy to the intestinal ecosystem. Ann Fr 322 Anesth Reanim 19:395-402.

23. Bussen S, Zimmermann M, Schleyer M, Steck T. (1997) Relationship of bacteriological 324 characteristics to semen indices and its influence on fertilization and pregnancy rates after IVF. Acta Obstet Gynecol Scand 76:964-968. 
Figure 1 : Evolution of the activity (number of semen analysis versus number of medical 328 consultations) between 2003 and 2008

330

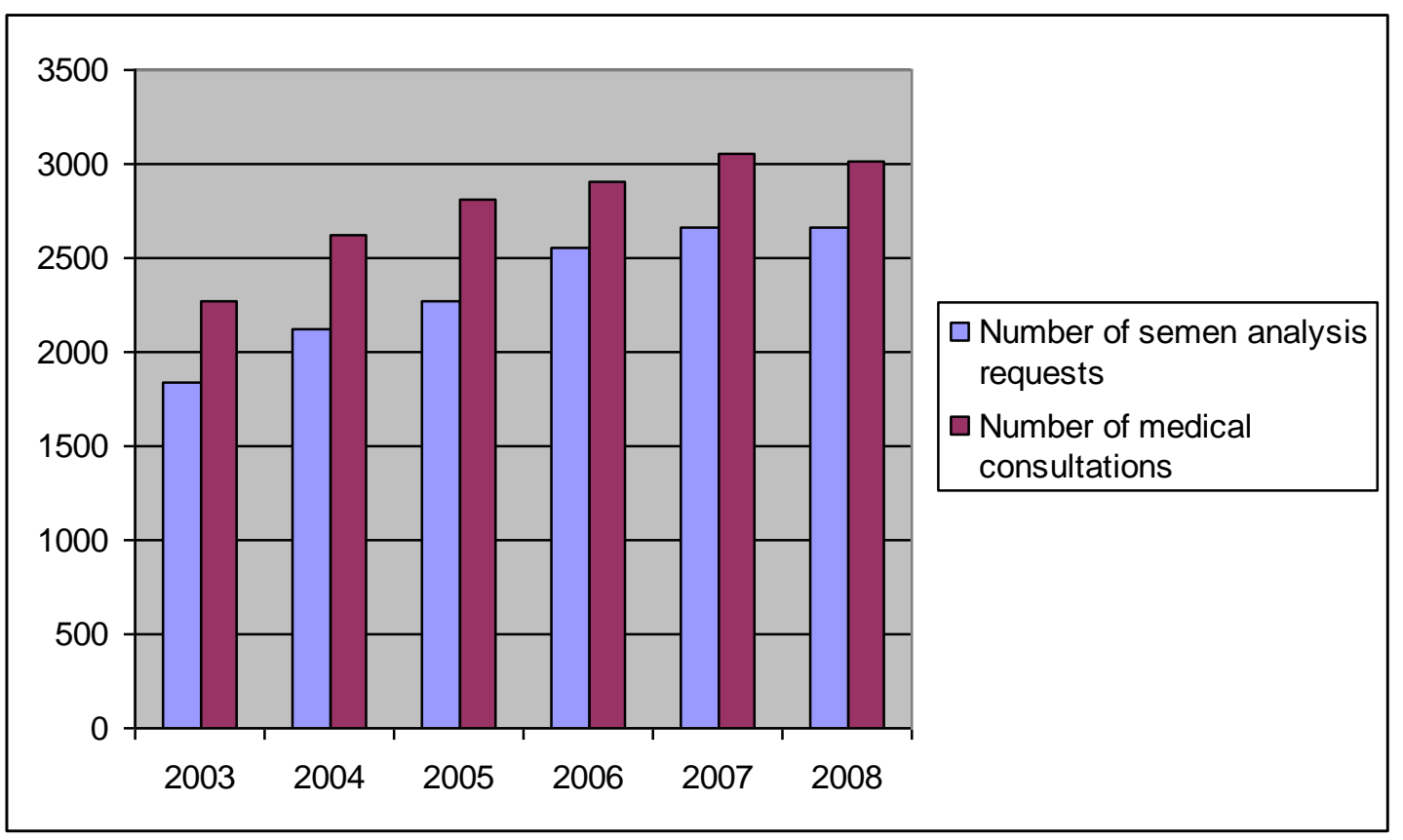


Table 1 : Evolution and characteristics of semen culture requests, at Nantes University Hospital,

2003

2004

2005

2006

2007

2008

Number of requests

Number of patients

< $1000 \mathrm{CFU} / \mathrm{mL}$

$>$ ou $=1000$ et $<3000 \mathrm{CFU} / \mathrm{mL}$

1 type of microbial colonies

2 types of microbial colonies

3 types of microbial colonies

4 types of microbial colonies

$>$ or $=5$ types of microbial colonies

ou $=3000 \mathrm{CFU} / \mathrm{mL}$

1 type of microbial colonies

2 types of microbial colonies

3 types of microbial colonies

4 types of microbial colonies

$>$ or $=5$ types of microbial colonies

Uninterpretable*

Insufficient amount

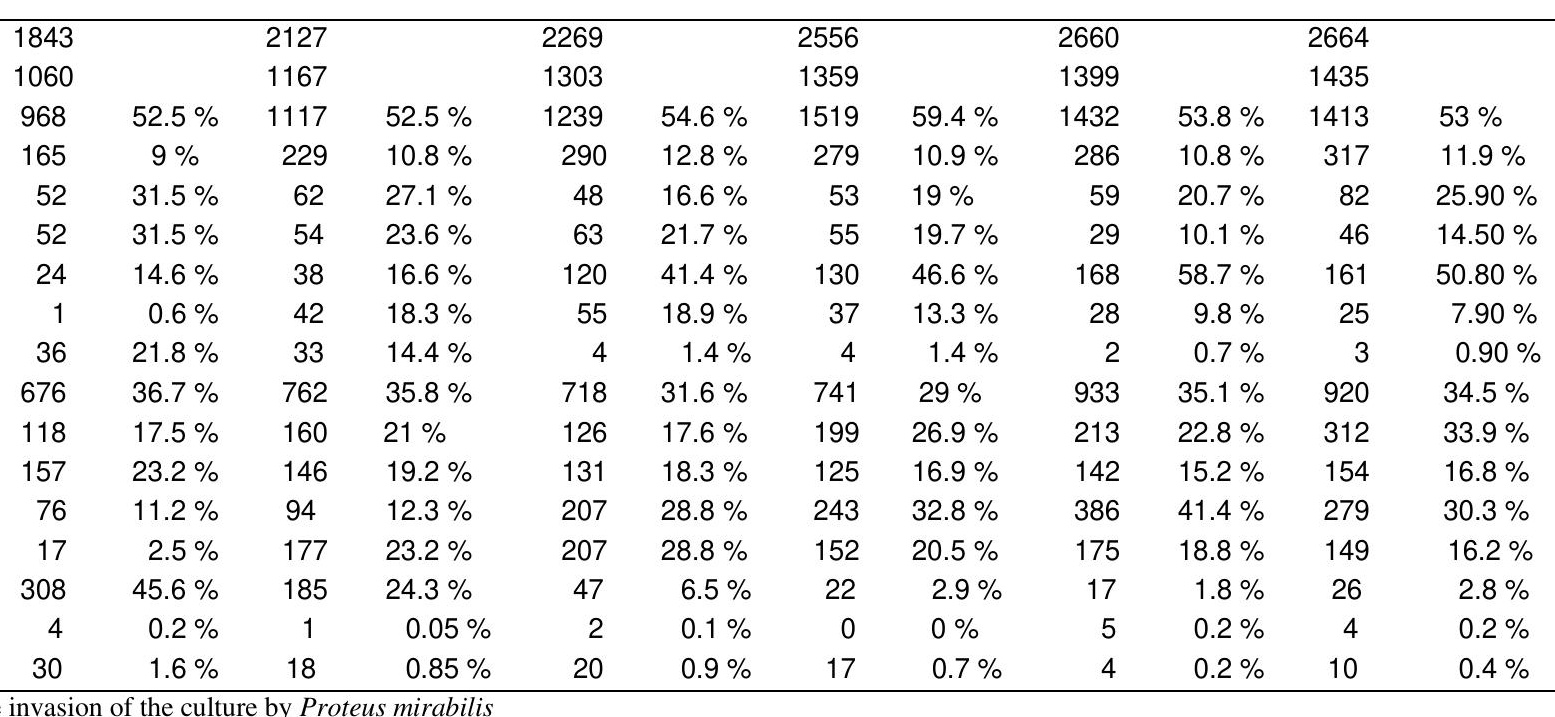


Table 2 : Distribution of bacterial species isolated from semen cultures, at Nantes University hospital, between 2003 and 2008

\begin{tabular}{|c|c|c|c|c|c|c|c|c|c|c|c|c|}
\hline & \multicolumn{2}{|c|}{2003} & \multicolumn{2}{|c|}{2004} & \multicolumn{2}{|c|}{2005} & \multicolumn{2}{|c|}{2006} & \multicolumn{2}{|c|}{2007} & \multicolumn{2}{|c|}{2008} \\
\hline & $\mathrm{N}$ & $\%$ & $\mathrm{~N}$ & $\%$ & $\mathrm{~N}$ & $\%$ & $\mathrm{~N}$ & $\%$ & $\mathrm{~N}$ & $\%$ & $\mathrm{~N}$ & $\%$ \\
\hline alpha-haemolytic Streptococci & 288 & 34.3 & 187 & 32.6 & 126 & 28.9 & 144 & 27.1 & 115 & 21.9 & 258 & 33.7 \\
\hline coagulase negative Staphylcocci & 235 & 28 & 107 & 18.7 & 78 & 17.9 & 111 & 20.9 & 93 & 17.8 & 155 & 20.2 \\
\hline Enterococcus & 159 & 19 & 60 & 10.5 & 82 & 18.8 & 105 & 19.8 & 128 & 24.4 & 136 & 17.7 \\
\hline Group B Streptococcus & 16 & 1.9 & 27 & 4.7 & 24 & 5.5 & 20 & 3.8 & 22 & 4.2 & 25 & 3.3 \\
\hline Staphylococcus aureus & 1 & 0.1 & 5 & 0.9 & 4 & 0.9 & 8 & 1.5 & 3 & 0.6 & 6 & 0.8 \\
\hline$\beta$-haemolytic Stretococcus & 10 & 1.2 & 4 & 0.7 & 4 & 0.9 & 7 & 1.3 & 7 & 1.3 & 1 & 0.1 \\
\hline Escherichia coli & 56 & 6.7 & 101 & 17.6 & 63 & 14.4 & 75 & 14.1 & 92 & 17.6 & 111 & 14.5 \\
\hline Proteus/Providencia/Morganella & 13 & 1.5 & 22 & 3.8 & 15 & 3.5 & 16 & 3 & 20 & 3.8 & 45 & 5.9 \\
\hline Other Enterobacteria & 29 & 3.5 & 31 & 5.4 & 27 & 6.2 & 26 & 4.9 & 32 & 6.1 & 22 & 2.9 \\
\hline Pseudomonas aeruginosa & 1 & 0.1 & 2 & 0.4 & 4 & 0.9 & 2 & 0.4 & 1 & 0.2 & 4 & 0.5 \\
\hline Corynebacterium seminale & 17 & 2 & 21 & 3.7 & 3 & 0.7 & 2 & 0.4 & 1 & 0.2 & 3 & 0.4 \\
\hline Others & 14 & 1.7 & 6 & 1 & 6 & 1.4 & 15 & 2.8 & 10 & 1.9 & 0 & 0 \\
\hline Total & 839 & 100 & 573 & 100 & 436 & 100 & 531 & 100 & 524 & 100 & 766 & 100 \\
\hline
\end{tabular}


Table 3 : Evolution of number of antibiotic susceptibility testing between 2003 and 2008. 344

\begin{tabular}{cccc}
\hline Years & Number of requests & $\begin{array}{c}\text { Number of antibiotic } \\
\text { susceptibility testing }\end{array}$ & $\begin{array}{c}\text { Number of MDR } \\
\text { bacteria }\end{array}$ \\
\hline 2003 & 1843 & 308 & 2 \\
2004 & 2127 & 307 & 1 \\
2005 & 2269 & 220 & 2 \\
2006 & 2556 & 205 & 0 \\
2007 & 2660 & $144^{*}$ & 4 \\
2008 & 2664 & 192 & 1 \\
Total & 14119 & 1376 & 10 \\
\hline
\end{tabular}

346 * In agreement with ART physicians, antibiotic susceptibility testing were stopped for Enterococci since the end of the year 2006. 